\title{
The Stream of Consciousness and the Epochal Theory of Time
}

\section{Maria Teresa Teixeira}

\section{(2) OpenEdition}

\section{Journals}

Electronic version

URL: http://journals.openedition.org/ejpap/872

DOI: 10.4000/ejpap.872

ISSN: 2036-4091

\section{Publisher}

Associazione Pragma

\section{Electronic reference}

Maria Teresa Teixeira, "The Stream of Consciousness and the Epochal Theory of Time », European Journal of Pragmatism and American Philosophy [Online], III-1 | 2011, Online since 01 July 2011, connection on 01 May 2019. URL : http://journals.openedition.org/ejpap/872 ; DOI : 10.4000/ ejpap.872

This text was automatically generated on 1 May 2019.

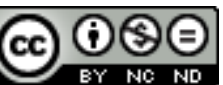

Author retains copyright and grants the European Journal of Pragmatism and American Philosophy right of first publication with the work simultaneously licensed under a Creative Commons AttributionNonCommercial-NoDerivatives 4.0 International License. 


\title{
The Stream of Consciousness and the Epochal Theory of Time
}

\author{
Maria Teresa Teixeira
}

1 William James is widely known as one of the theorizers of pragmatism, and also for his pioneering work on consciousness. Jamesian pragmatism relates to the rejection of intellectualism, and from an early stage to the notion of thought, or consciousness depicted as a continuous flux, like a "river" or a "stream." "Later in his philosophical development, James also pictured the world as something unfinished that flows and keeps growing.

2 In William James's philosophy, rationalism is contrasted to pragmatism: "for rationalism reality is ready-made and complete from all eternity, while for pragmatism it is still in the making, and awaits part of its complexion from the future." What emerges then is what is still in the making, not what is completed and pre-established. Real existence consists of real things, which are in the process of coming into being. We can actually apprehend these things that are 'still in the making' by a stroke of intuition. But they are not ready-made and clear-cut; also, they do not lie about awaiting our appropriation of them. Reality is a process of coming into being, a flux that unravels itself so that it can achieve its own existence. Reality "mounts in living its own undivided life - it buds and burgeons, changes and creates."

William James can thus be considered as one of the forefathers of process philosophy. His philosophy was certainly an enduring inspiration for other process philosophers such as Henri Bergson and Alfred North Whitehead, and it gave rise to a new literary genre: the stream-of-consciousness novel. We can count Virginia Woolf, James Joyce and Marcel Proust as some of the most illustrious writers who have explored this technique.

4 In The Principles of Psychology consciousness and its temporal succession are presented as a continuous stream. Thought is in a continual change. James depicts thought as something that "goes on": "Within each personal consciousness, thought is sensibly continuous." ${ }^{5} \mathrm{He}$ says that "continuous" should be defined as "that which is without breach, crack, or division." Consciousness cannot be divided into bits; on the contrary, it flows like a stream. However, we can identify different states of consciousness within the flow. But they are 
not external or contiguous to one another. There is a relatedness that accounts for the continuity of the flow of consciousness, although there is no recurrence of the same state of consciousness. This is the reason why we never think the same thing twice. James anticipates here what will be established later in the philosophies of Bergson and Whitehead's as the irreversibility of time.

In chapter IX of his Principles of Psychology, entitled "The Stream of Thought" he writes:

Every thought we have of a given fact is, strictly speaking, unique, and only bears a resemblance of kind with other thoughts of the same fact. When the identical fact recurs, we must think of it in a fresh manner, see it under a somewhat different angle, apprehend it in different relations from those in which it last appeared. ${ }^{6}$

Every state of consciousness is different from every other state of consciousness; there are no frozen, permanent thoughts making their appearance every now and then in consciousness. Also, every thought is a novel state of consciousness, no matter how close it may resemble other thoughts. Recognition is the effort of bringing into consciousness an old idea, so that it can be the "same" idea. This effort must be considered as something extra that adds on to the original idea and thereby introduces novelty.

7 The early James thus seems to consider memory as a psychological effort that reconstructs an old idea. We will see later that, from the very beginning, the idea of an ontological past is implicit to James's philosophy in so far as he emphasises the introduction of novelty in his temporal stream of consciousness. Novelty is indeed a character of temporality; novel temporal states emerge from an ontological past that constitutes them in absolute novelty. However, James only admits to an ontological past in his late writings as a consequence of Bergson's influence.

The novel states of consciousness that emerge can be identified and individualized. They seem to crack the stream of consciousness if we consider them as independent units. In fact, they are discrete units and exhibit a character of discontinuity. However, the flow of consciousness persists; distinctness does not break the continuous, ongoing activity of consciousness. "A silence may be broken by a thunder-clap, and we may be stunned and confused for a moment by the shock as to give no instant account to ourselves of what has happened. But the very confusion is a mental state, and a state that passes us straight over from the silence to the sound. The transition between the thought of one object and the thought of another is no more a break in the thought than a joint in a bamboo is a break in the wood. It is a part of the consciousness as much as the joint is a part of the bamboo."

9 James compares the stream of our consciousness to a bird's life "made of an alternation of flights and perchings." Also he calls "the resting-places the 'substantive parts,'and places of flight the 'transitive parts,' of the stream of thought." These transitive parts i.e. the places of flight of the flux account for the unity of thought. This metaphor has frequently been misinterpreted.

Henri Bergson criticised this distinction in a letter he wrote to William James in January $1903,{ }^{10}$ and in another one he wrote to Floris Delattre years later in $1923 .{ }^{11}$ He writes that in his durée réelle there is no flight, and no rest. In other words, there is no instantaneous immobility, no static places of rest. Only transition is real. Reality is continuous and indivisible change. He considers the stream of thought to have a psychological nature, whereas his durée is metaphysical. Bergson's criticism seems to draw a line between his durée réelle and James's stream of thought. 
11 On a closer examination, however, Bergson's durée is in fact quite near the Jamesian stream of thought. The resting-places in the stream of consciousness cannot be considered as "breaks in the thought." There are no "cracks" in the stream of thought, only soft patterns and stream-flows. On the other hand, Bergson's continuous flux is not homogeneous and its continuity should not be confused with the mathematical continuity of time, which is not true duration. It is but an endless repetition of the same mathematical element. The Bergsonian continuous flux is a dynamic continuity; also, the heterogeneity of duration is the true character of reality. Different states of consciousness succeed one another introducing thereby novelty in this continuity. Hence, there are no two identical states of consciousness; they always differ even when they exhibit a close resemblance. For duration carries novelty within itself. James's restingplaces in the stream of consciousness are thus comparable to the heterogeneity of the durée réelle.

Bergson seems to acknowledge this argument in his preface to the French translation of William James's work on Pragmatism. He writes: "To be sure, our experience is not incoherent. At the same time as it presents us with things and facts it shows us relationships between the things and connections between the facts: these relations are as real, as directly observable, according to William James, as the things and facts themselves. But the relations are fluctuating and the things fluid. This is vastly different from that dry universe constructed by the philosophers with elements that are clear-cut and well-arranged, where each part is not only linked to another part, as experience shows us, but also, as our reason would have it, is coordinated to the whole." ${ }^{12}$ The resting-places are now "the things that are fluid," and the places of flight "the relations that are fluctuating." There are no static places of rest, no instantaneous immobility; things endure in their inescapable, continuous flow. James's stream of thought exhibits no clearcut divisions; the succession of states is a flow from one state to the next: interpenetration, as Bergson would call it.

13 This heterogeneous, continuous flow can be described as epochal. For it presents discontinuities that can be identified as distinct phases in the flow of reality, which are not to be considered as "cracks" in the stream. Process philosophers have developed distinctive epochal theories of time. William James argued that the stream of our experience comes in discrete durational units. Alfred North Whitehead held that "Time is sheer succession of epochal durations." ${ }^{13}$ Henri Bergson emphasized the qualitative multiplicity characterising the states of our consciousness. However, all three conceptions of consciousness and temporality are quite close.

14 Bergson mostly emphasised continuity. He is often misinterpreted and his continuity is taken for an undifferentiated flow that unravels in ceaseless glide. However, the Bergsonian flow is multifarious and does not preclude an abundant diversity of states of consciousness. As the flow unravels, it carries all the indestructible past that is present to the novel present that unrolls. The ontological past allows for the emergence of novelty; the emergence of novelty is only possible because temporality is duration. Different states of consciousness endure in such a way that their particular way of enduring characterises and differentiates them absolutely. They draw on the indestructible past for their coming into being; and the ontological past necessitates the emergence of the novel for it reinvents itself as the flow of consciousness is enriched by the novel states of consciousness. This heterogeneous flow is thus epochal; different states of consciousness are identifiable although they are not clear-cut and separate. The Bergsonian durée 
endures and in so doing characterises absolutely each and every state of consciousness that cannot, nevertheless, be separated from the entire flux. Inseparability and heterogeneity thus describe epochal time.

Whitehead emphasises what he calls the atomic character of reality. He is also often misinterpreted. Actual entities, the basic entities of reality, "the final real things" are of a temporal nature; they become and perish because of their temporal nature. This is often a point where some commentators grossly misinterpret Whiteheadian philosophy. They confuse the atomicity of becoming with clear-cut fixity, the indivisibility of becoming with the subsequent coordinate analysis of the actual entity that has attained satisfaction, i.e. completion. Actual entities are "drops of experience"; as such they are individualised and become as indivisible wholes. Their atomic character lies in their individualisation and their indivisibility. Each entity is said to be an epochal duration for it is temporal and individualised. "The epochal duration is not realised via its successive divisible parts, but is given with its parts." ${ }^{14}$ Once actual entities have become as temporal wholes, they perish subjectively; but they also become transcendent and are thus objectively immortal. This means that the past is immortal and forever irrevocable. It will be the data for future actual entities, i.e. the next actual occasions will prehend previous entities and grow together to form a novel entity. Prehension is appropriation. Novel actual entities appropriate the past so that they can become into a totally novel synthesis. The past is constitutive of novel entities and thus reveals its ontological nature. It conditions them although it does not determine them in an absolute way.

Whitehead and Bergson's ontological pasts are very similar: irrevocability and indestructibility result from novelty that is ever present in the temporal unravelling of reality. This new concept of temporality greatly diverges from the traditional notion of time that seems to originate from Saint Augustine. In Augustine's doctrine the past does not seem to be indestructible, nor does it seem to have any existence because past things cannot be found anywhere: "For if there are times past and future, I wish to know where they are. But if I have not yet succeeded in this, I still know that wherever they are, they are not there as future or past, but as present. For if they are there as future, they are there as 'not yet'; if they are there as past, they are there as 'no longer.' Wherever they are and whatever they are they exist therefore only as present." ${ }^{15}$ Only the present seems to have existence: the past is there "no longer" and the future is not there yet. However, Augustine seems to identify some coexistence of the present with the past when he names three distinct times as: "a time present of things past; a time present of things present; and a time present of things future." ${ }^{16} \mathrm{He}$ also emphasises that the three times coexist in the soul and that the "time present of things past" is memory. In a certain sense, we could say that Augustine's memory is already ontological for he seems to be aware that it constitutes present beings. Also, the present seems to have a certain thickness because, in a certain sense, it coexists with the past and tends to already include an expectant future.

Temporality and continuity are thus important themes in process philosophy. James's philosophy as a philosophy of process is not a philosophy of substances, or a philosophy of things. He is mainly concerned with time, change and discontinuity. James's analysis tries to find out if the additions to the existing reality have a continuous, or a discontinuous nature. One could say this is the founding inquiry concerning the epochal theory of time. Indeed the inquiry about continuity and discontinuity is an ever-present question in almost all philosophies of process. Zeno's famous arguments against motion 
and its paradoxes are an old favourite of Western philosophy, and also of process philosophies.

William James discusses the question of discontinuity as well as Zeno's paradoxes in chapters X and XI of his Some Problems of Philosophy, ${ }^{17}$ both entitled "Novelty and the Infinite." He writes: "On the discontinuity-theory, time, change, etc., would grow by finite buds or drops, either nothing coming at all, or certain units of amount bursting into being 'at a stroke'." ${ }^{18}$ In other words, reality either grows by abrupt units of being that emerge by a single action, which is an addition of novelty, or it does not grow at all. These novel additions to reality are finite and indivisible. However, due to the excessive intellectualism of our ways of thinking, we tend to consider that novel additions to reality are a set of infinite, innumerable steps, which can always be divided into ever-smaller units.

Nevertheless, reality can be said to have an atomistic constitution, but only in the sense that there are whole, indivisible units of duration and extension that come into being at one stroke. Reality has a discrete composition, and our knowledge of reality grows by "buds," or "drops" of experience. We either have an experience that is whole and given by a single action, or we have no experience at all. Jamesian atomism (as well as Whiteheadian atomism) should not be misunderstood. The units that compose reality are atomic because they are undivided and individualized. The discrete constitution of reality does not allow for divisibility ad infinitum. Atoms are undivided and indivisible wholes; also, they are complex syntheses.

The question of continuity and discontinuity is an old inquiry that has haunted philosophy for centuries. Zeno, the Eleatic was the first to formulate the question of divisibility ad infinitum. He was primarily concerned with showing that motion did not really exist. Zeno's paradox of the flying arrow attempts to demonstrate that if the arrow occupies successive points in space, its motion is nothing more than a sum of its positions in space; thus truly the arrow does not move. As Aristotle had already pointed out, "the flying arrow is at rest." ${ }^{19}$ William James states: "If a flying arrow occupies at each point a determinate point of space, its motion becomes nothing but a sum of rests, for it exists not, out of any point; and in the point it doesn't move." ${ }^{20}$

In the Achilles paradox, Achilles' race to overtake the tortoise is also reduced to a collection of successive points with no extension or duration. According to Zeno, Achilles never manages to overtake the tortoise because he must occupy all the successive points where the tortoise has been positioned. Each time he gets to the tortoise's last position, the tortoise has already moved to a next successive point. So Achilles, in order to catch the tortoise, would have to do the incredible thing of reaching the end of an endless series.

The mathematical notion of a continuum (not to be confused with a qualitative or dynamic continuum) arises from Zeno's paradoxes. The mathematical continuum can be infinitely divided. It is composed of exterior, contiguous elements, endlessly repeated. It differs from a qualitative continuum, such as James's stream of thought or Bergson's continuity of change in that it does not allow for novelty and real duration. In the real world there are no small intervals of time that can be divided ad infinitum, no instants without any duration, which would be the only truly indivisible units of time. Time has thickness; there is no infinite divisibility of time, no mathematical instant corresponding to the present. In his Principles of Psychology, James describes duration: 
The unit of composition of our perception of time is a duration, with a bow and a stern, as it were - a rearward-and a forward-looking end. It is only as parts of this duration-block that the relation of succession of one end to the other is perceived. We do not first feel one end and then feel the other after it, and from the perception of the succession infer an interval of time between, but we seem to feel the interval of time as a whole, with its two ends embedded in it. The experience is from the outset a synthetic datum, not a simple one; and to sensible perception its elements are inseparable, although attention looking back may easily decompose the experience, and distinguish its beginning from its end. ${ }^{21}$

As we have said, James metaphorically refers these units of duration as "drops or buds" of experience; they are also "pulses" of reality. ${ }^{22}$ These units of duration, which make up time, are whole, finite and indivisible. If they were otherwise, if those drops of experience included a changing process, then again we would have Zeno's paradox and their process of being could never be completed. If time were infinitely divisible, as is required by our intellectualist logic, then, we would not be able to reach the end of any temporal experience, like Achilles and the tortoise:

That being should immediately and by finite quantities add itself to being, may indeed be something which an onlooking intellect fails to understand; but that being should be identified with the consummation of an endless chain of units (such as points), no one of which contains any amount whatever of the being (such as "space") expected to result, this is something which our intellect not only fails to understand, but which it finds absurd. ${ }^{23}$

If time were infinitely divisible it could not elapse, for no end could be reached. No matter how much time had already passed, before the remainder could elapse, the earlier part of it should first pass; the earlier half should always elapse first, so that no end could ever be reached. This can be expressed by the convergent series: $1 / 2,1 / 4,1 / 8,1 / 16 \ldots$

James solves this problem of the "infinite regress" in Zeno's paradoxes by postulating an epochal theory of time; he proposes that time comes in discrete units of duration, which are whole, indivisible and unchanging. If they were not so, i.e. if they were an everchanging divisible process, time would again appear to be a mathematical continuum made of tautological repetitions.

6 Units of duration, also called epochs by Alfred North Whitehead, are changeless indivisible wholes that succeed each other. They are, all of them, diverse wholes that introduce novelty into reality. Whitehead expresses this unchangeable nature of durational wholes in his own peculiar phraseology: "Actual entities perish, but do not change; they are what they are." ${ }^{24} \mathrm{He}$ also writes: "There is a becoming of continuity, but no continuity of becoming." ${ }^{25}$

Whitehead's interpretation of Zeno's paradoxes is based on James's approach. Whitehead emphasises the mathematical solution of Zeno's paradoxes, but still he maintains that these sophisms endanger mainly our treatment of becoming and time. ${ }^{26}$ Whitehead says that, according to Zeno, every act of becoming requires an immediate predecessor. However, this need for an immediate predecessor implies an additional premise that is not found in Zeno's paradoxes. Instead, there is a "vicious infinite regress," which can only be over-come by postulating an epochal theory of time. Durational units are atomic, in the sense that they are whole, indivisible, complex, individualized, and changeless; becoming is by its very nature changeless: "there is a becoming of continuity, but no continuity of becoming." Becoming implies the rejection of its own divisibility and change whilst becoming proceeds, as well as the constitution of a novel individual entity: 
The conclusion is that in every act of becoming there is the becoming of something with temporal extension; but the act itself is not extensive, in the sense that it is divisible into earlier and later acts of becoming which correspond to the extensive divisibility of what has become. ${ }^{27}$

Thus the temporal process is a process of wholeness: "The epochal duration is not realised via its successive divisible parts, but given with its parts." 28

In Whitehead's philosophy, the indivisible basic temporal unit, the actual occasion endures through a certain period. This endurance is its coming into being; it is also its own effect of distinctiveness, i.e. the actual occasion becomes as it is because it has its own particular way of becoming, it has its own period of becoming and being. Each actual occasion is an epoch, i.e. an arrest. This arrest is comparable to James's places of rest; it is not a break in the continuity of reality, but it allows for individualization. Actual occasions are individuals, even though they are not external to each other. The passage of things is not "a mere linear procession of discrete entities." ${ }^{29}$ Discreteness is indeed a character of actual occasions, but there is no linearity in their process of coming into being. Durational units can thus be individualized; that is the very reason why they are atomic and epochal.

Nevertheless, Whitehead's discontinuities do not imply the denial of continuity between actual occasions. They do imply, however, that the process of constitution of an actual occasion is not divisible into other component processes which would be themselves actual occasions. In other words, becoming is not composed of other acts of becoming.

1 The process of becoming does not occur in time because it is the very creation of time; the act of becoming is whole and indivisible. Becoming is not included in a pre-existing container where it can come about at a certain instant. Rather it is a temporal epoch that is created by its process of coming into being; temporal epochs have duration, and are not instantaneous. Their completion supplies them with actuality, but their distinctiveness and individualization comes from their durational nature, which defines and determines their coming into being. Once they have become, actual occasions, which we could also call durational units, perish and are prehended or appropriated by other novel actual occasions, which thus initiate their own process of becoming. Time unveils "a sheer succession of epochal durations," but it is by its very nature incomplete. Novel actual entities succeed one another so that process is never completed; indeed it could not be so, for it would not be process otherwise. The Whiteheadian epochal theory of time implies that every actual occasion has a spatial volume; it atomizes reality but does not break it into pieces, neither does it crack continuity. ${ }^{30}$ For "there is a becoming of continuity."

Bergson also examines Zeno's paradoxes. Bergson is mainly concerned with the indivisibility of motion. He states that Achilles does not occupy the successive positions occupied by the tortoise. He does not fall into step with the tortoise; he simply runs and over-takes it. Bergson does not consider the mathematical solution, which deals with a sum of the infinite geometric series that results in a finite number, ${ }^{31}$ nor is he concerned with the question of infinite regress and infinite divisibility. He holds that Achilles steps differ from the steps of the tortoise. Achilles' steps do not reproduce the steps of the tortoise; neither does Achilles follow up the exact positions of the tortoise. He simply runs and overtakes it! Achilles does not occupy the successive points in space occupied by the tortoise. Bergson writes: "All points of space necessarily being fixed, I must be careful not to attribute to the moving object itself the immobility of the point with which it coincides [...] How can a progress coincide with a thing, a movement with an immobility?" ${ }^{32}$ 
In Creative Evolution, Bergson again considers Zeno's paradoxes: “At bottom, illusion arises from this, that the movement, once effected, has laid along its course a motionless trajectory on which we can count as many immobilities as we will. From this we conclude that the movement, whilst being effected, lays at each instant beneath it a position with which it coincides. We do not see that the trajectory is created in one stroke, although a certain time is required for it; and that though we can divide at will the trajectory once created, we cannot divide its creation, which is an act in progress and not a thing." ${ }^{33}$ Bergson distinguishes real movement from the motionless trajectory along its course, which can be drawn after the movement is completed. Motion is whole and indivisible; it takes time and flows uninterruptedly; the line of its trajectory is a mere postrepresentation of a durational reality. Duration is in fact the primordial fact characterizing reality.

Thus, as we said above, Bergson's durée can also be considered as epochal. The continuous flow of reality seems to preclude temporal units distinguishable from each other. But the continuous flow is made up of states of consciousness that interpenetrate and are referred to as "states," even though they are not external to each other. Lack of externality does not mean absence of distinctness. Rather it means there is a qualitative multiplicity. In Introduction to Metaphysics, Bergson writes:

Shall we say that this duration has unity? Undoubtedly a continuity of elements prolonged into one another partakes of unity as much as it does of multiplicity. But this moving, changing, coloured and living unity scarcely resembles the abstract unity, empty and motionless, which the concept of pure unity circumscribes. ${ }^{34}$

Duration is thus qualitative and heterogeneous. In consciousness we find states that succeed each other and melt into one another. ${ }^{35}$

Thus duration is continuous but it also consists of discrete units, which can be designated as epochs. There are different rhythms of duration that can be identified as temporal units, each one diverse from the other. In Matter and Memory, Bergson writes:

In reality there is no one rhythm of duration; it is possible to imagine many different rhythms which, slower or faster, measure the degree of tension or relaxation of different kinds of consciousness, and thereby fix their respective places in the scale of being. ${ }^{36}$

Each rhythm of duration, we could say, is a temporal unit, for it defines each creature absolutely providing it with its own way of being, which is of durational nature. Rhythmical entities require the existence of discrete units; for without them there would be no rhythm. These rhythms can thus be identified, and although they are continuous within the flow of reality, they are distinguishable from one another. They can thus be considered as epochal. In Bergson's philosophy the epochs emerge as the successive interpenetrating states of consciousness; they are time as it is lived by our consciousness.

Consciousness is the Bergsonian paradigm for duration of all entities. Bergson extends the application of the notion of consciousness to the material world to point up the similarity between different levels of duration. This analogy should not be misunderstood; neither should it be taken in a literal sense. Whitehead found a better term to express the same thing: "prehension." He too conceives the ultimate elements of matter with a vibratory character. Bergson and whitehead tried to express that matter, as well as life have duration. Matter endures in a much quicker rhythm than the rhythm of our consciousness. Our perception of the world involves the contraction of these material vibrations and thus reconciles the different modes of enduring. Every creature 
endures and has, therefore, an elementary level of memory, which Bergson designates, borrowing from Espinoza, as 'mensmomentanea.' This ontology of matter precludes the instantaneous and establishes reality as undeniably epochal. "All duration has thickness; real time has no instants." ${ }^{37}$

William James also holds that creatures differ amongst themselves in accordance with duration..$^{38}$ Their "specious present" may be more, or less contracted. His notion of the "specious present" asserts, "The unit of composition of our perception of time is a duration." ${ }^{39}$ James borrows the idea of the 'specious present' from E. R. Clay: "Time, then, considered relatively to human apprehension, consists of four parts, viz., the obvious past, the specious present, the real present, and the future. Omitting the specious present, it consists of three [...] nonentities - the past, which does not exist, the future, which does not exist, and their conterminous, the present; the faculty from which it proceeds lies to us in the fiction of the specious present." 40 The "specious present" is a misleading designation for it suggests that the present lived by our consciousness is not truly real. According to E. R. Clay the real present is the instantaneous mathematical present. If each fraction of time is infinitely divisible into smaller and smaller elements, we can but conclude that the real present is an instant without duration and thus the existing present is instantaneous. Indeed, what is true is the very opposite: the so-called "specious present" is the time lived by our consciousness that has always some thickness, and its own determined rhythm. Real time is epochal whether endured by our consciousness, or by matter. Otherwise, it would not be real time.

For Bergson, as well as for James and Whitehead the present is not an instant without duration. The present time has thickness; it endures and thus relates to the past. In his Principles of Psychology, James writes: "Duration and events together form our intuition of the specious present with its content." ${ }^{41}$ It is worthy to note that in James's doctrine duration does not yet coincide with events, as it does in Whitehead's philosophy, or with the flux of consciousness, as it does in Bergson's theory. He states:

the distinctly intuited present merges into a penumbra of mere dim recency before it turns into the past which is simply reproduced and conceived. [...] This sense of recencyis a feeling sui generis, and may affect things that happened hours ago. It would seem to show that their brain-processes are still in a state modified by the foregoing excitement, still in a "fading" phase, in spite of the long interval. ${ }^{42}$

James distinguishes two pasts: one that is "directly intuited" and another that is "simply reproduced and conceived." The former correlates with primary memory, the latter with "memory proper or secondary memory." This distinction is important because it asserts that the only true past is the one that mingles with the specious present, and in a certain way coincides with it; also, it seems to depend wholly on material brain-processes, without which the "fading" phase would be impossible. The sense of "recency" is the main feature of this kind of memory. On the other hand, "memory proper" is always indirect recall: recollection is not a past state, but a present one that succeeds a past state that has for ever vanished. Consequently, recollection is a present state that is completely external to the past state that originated it; the past state no longer exists and the recollection is simply a similar duplicate that exists in the present.

The past not directly apprehended is dead and gone; it has no ontological existence, even though it may leave behind material traces in the brain. The stream of consciousness thus seems to flow into nonentity. The past is not integrated into the stream; the different states simply fade away and vanish. 
we consider other process philosophies we will find that the past has a different status. Bergson holds that the past engulfs the new states of consciousness and preserves them, so that every novel state incorporates every previous state. He stresses the flux of reality as well as the persistence of the past, which is carried by it. The Bergsonian durée carries novelty within itself as it creates reality; and it pursues its course carrying all the indestructible past. The past is present to the present; Gilles Deleuze speaks of a contemporaneity of the present with the past in Bergson's philosophy. ${ }^{43}$ Also, the past preserves itself because it endures:

But only then did I become aware of the fact that inward experience in the pure state, in giving us a "substance" whose very essence is to endure and consequently continually to prolong into the present an indestructible past, would have relieved me from seeking, and would even have forbidden me to seek, where memories are preserved. They preserve themselves [...]. ${ }^{44}$

Memory is by its very essence duration; so there is no place really where we can find it. This is the reason why Bergson holds that pure memory is immaterial and cannot be found in the brain:

To make the brain the depository of the past, to imagine in the brain a certain region in which the past, once past, dwells, is to commit a psychological error, to attribute a scientific value to a distinction entirely practical, for there is no exact moment when the present becomes the past, nor consequently when perception becomes recollection. ${ }^{45}$

The fact that the past is present to the present does not allow for any exactness in the distinction of present and past, neither does it permit of any real local- ization. The flow of consciousness, although uninterrupted, preserves the whole past within itself.

I believe that our whole psychical existence is something just like this single sentence, continued since the first awakening of consciousness, interspersed with commas, but never broken by full stops. And consequently I believe that our whole past still exists. It exists subconsciously [...]. ${ }^{46}$

The flow of consciousness, which is whole, is also epochal; its indivisibility attests to the indestructibility of the past, which can nevertheless be identified in different epochs. Also, Bergson considers that it can manifest itself in its wholeness as a present experience (cf. the near-death experience of life-review). This manifestation is of psychological nature, although the past itself is ontological.

Conversely, James seems to admit only present mental states, for he seems to deny any ontological status to the past considering only conscious states directly intuited.

So far, in the treatment of memory, we have but referred the early philosophy of William James. However, in our previous analysis of the stream of consciousness we considered the later James and concluded that the addition of discrete elements to reality characterizes a stream of thought without any breaks. We also spoke of recognition as the effort of bringing into consciousness an old idea so that it can be the "same" idea. This effort was then considered as a new addition that introduced novelty; novel states of consciousness could be identified as distinct from each other, but they did not break the stream that persisted in its flow. We also quoted in favour of our theory from James's late work, although we could already find our argument in Principles of Psychology, in its chapter on the stream of thought, from which we also quoted. We can now say that the introduction of novel, discrete additions in the stream of consciousness, in some way, attests to the persistence of an ontological past and the irreversibility of time, even though James is not clear about this point and sometimes even contradicts it.

European Journal of Pragmatism and American Philosophy, III-1 | 2011 
we can resort to James's works on mysticism to find there an ontological, sublimina memory that seems to surpass Bergson's indestructible past and Whitehead's immortality of the past. In The Varieties of Religious Experience James refers the subconscious self as a "psychological entity." He quotes from Myers's essay on subliminal consciousness that establishes that the self is far more extensive than it can know or manifest. James then comes to the conclusion that: "the fact that the conscious person is continuous with a wider self through which saving experiences come, [...] is literally and objectively true as far as it goes." ${ }^{47}$ Here William James comes quite close to Sri Aurobindo's concept of subliminal memory:

The surface memory itself is a fragmentary and ineffective action pulling out details from an inner subliminal memory which receives and records all worldexperience, receives and records even what the mind has nor observed, understood or noticed. Our surface imagination is a selection from a vaster more creative and effective subliminal image-building power of consciousness. A mind with immeasurably wider and more subtle perceptions, a life-energy with a greater dynamism, a subtle-physical substance with a larger and finer receptivity are building out of themselves our surface evolution. A psychic entity is there behind these occult activities which is the true support of our individualisation. ${ }^{48}$

In his late life, near to his death James wrote a paper called "A Suggestion about Mysticism" ${ }^{49}$ where he overtly accepts Bergson indestructible past and its ontological character. He refers the field of consciousness in a somewhat Bergsonian style:

The present field as a whole came continuously out of its predecessor and will melt into its successor as continuously again, one sensation-mass passing into another sensation-mass and giving the character of a gradually changing present to the experience, while the memories and concepts carry time-coefficients which place whatever is present in a temporal perspective more or less vast. ${ }^{50}$

Time is now real and responsible for the introduction of novelty. In a way it extends the temporality of the stream of consciousness, where novelty was already implied but not wholly developed. This extension depends on the recognition of the status of memory as ontological and constitutive of the different creatures.

5

It is not surprising then to find that that Whitehead's doctrine on time and creativity borrows a lot from James's theory. Whitehead's actual entities become and perish subjectively but remain forever as objectively immortal. Their perishing is a means of objectification, so that they can be apprehended and incorporated in the ontological constitution of their successors. This alternate perishing and coming into being is known as process. It is a creative activity for each actual entity that comes into being is selfcreating, although it draws from its predecessors. "The notion of prehension of the past means that the past is an element which perishes and thereby remains an element in the state beyond, and thus is objectified." ${ }^{51}$ Consequently novelty is always introduced into process; it goes on indefinitely and is never complete.

Thus each actual entity, although incomplete so far as concerns its microscopic process, is yet incomplete by reason of its objective inclusion of the macroscopic process. It really experiences a future which must be actual, although the completed actualities of that future are undetermined. In this sense, each actual occasion experiences its objective immortality. ${ }^{52}$ Incompleteness reveals itself in the determination of a future not yet determined but that will be erected on the objective immortality of actual occasions.

Thus Whitehead's past is ontological because it is constitutive of the actual entities; it is also irrevocable like Bergson's, and introduces novelty into reality. 

are founded on the principle of process. The flow of reality is uninterrupted, but it is also made of heterogeneous states that can be differentiated but not separated within the flux. The ontological, indestructible past adds novelty to reality for it refuses tautological repetition and unveils itself in the novelty of the present time.

\section{BIBLIOGRAPHY}

ARISTOTLE, (1995), The Complete Works, The Revised Oxford Translation, Jonathan Barnes (ed.), Princeton, New Jersey, Princeton University Press.

AUROBINDo Sri, (2000), The Life Divine, Pondicherry, Sri Aurobindo Ashram Press.

BERGSON Henri, (1944), Creative Evolution, translated by A. Mitchell, New York, Modern Library.

BERGSON Henri, (1972), Mélanges, Paris, Presses Universitaires de France.

BERGSON Henri, (1975), Mind-Energy Lectures and Essays, translated by Wildon Carr, Westport, Connecticut, Greenwood Press, Publishers.

BERGSON Henri, (2001), CEuvres, Paris, Presses Universitaires de France.

BERGSON Henri, (2002), Correspondances, Paris, Presses Universitaires de France.

BERGSON Henri, (2007), The Creative Mind, An Introduction to Metaphysics, Mineola, New York, Dover Publications, Inc.

BERGSON \& PERRY-GILLET, (2008), “Correspondance Inédite Bergson/Perry-Gillet, établissement du texte, traduction, annotation et présentation par Thibaud Trochu," Annales bergsoniennes IV L'Évolution créatrice 1907-2007: épistémologie et métaphysique, Paris, Presses Universitaires de France. BRACKEN Joseph A., S. J., (2009), "The Objective Reality of the Past: Some Further Reflections," in Process Studies, 38.1, 108-18.

CAPEK Milic, (1950), "Stream of Consciousness and 'Durée Réelle'," Philosophy and Phenomenological Research, 10 (3), 331-53.

CAPEK Milic, (1972), “The Fiction of Instants,” The Study of Time, 1, New York, Springer-Verlag, $332-44$.

CAPEK Milic, (1977), “Immediate and Mediate Memory," Process Studies, 7.2, 90-6.

CAPEK Milic, (1987), “The Conflict between the Relational Theory of Time before Newton,” Journal of the History of Ideas, 48 (4), 595-608.

CoDE Murray, (1985), Order \& Organism, Albany, State University of New York Press.

DELEUZE Gilles, (1998), Le bergsonisme, Paris, Presses Universitaires de France. 
DESMET Ronny, (2009), "Whitehead: Relativity and Experience," Concrescence - The Australasian Journal of Process Thought, 3-9. [concrescence.org/index.php/ajpt/article/view/67/31].

Dumoncel Jean-Claude, (2010), “La Métaphysique de l'événement," in M. Weber \& R. Desmet (eds), Chromatikon VI Annales de la philosophie en procès Yearbook of Philosophy in Process, Les éditions Chromatika.

FIELD Richard W., (1983), “William James and the Epochal Theory of Time," Process Studies, 13 (4), 260-74.

FORD Lewis S., (2009), “The Indispensability of Temporal Atomicity," Process Studies, vol. 38.2, 279-303.

JAMES William, (1950 unabridged reprinting), The Principles of Psychology, 2 vols., New York, Dover Publications, Inc.

JAMES William, (1987), Writings 1902-1910, The Varieties of Religious Experience, Pragmatism, A

Pluralistic Universe, The Meaning of Truth, Some Problems of Philosophy, Essays, New York, The Library of America.

JANKÉLÉVITCH Vladimir, (1989), Henri Bergson, Paris, Presses Universitaires de France.

ROGUE Évelyne, (1998), "Bergson ou un présent subspecies durationis," analyses et réflexions sur Henri Bergson La Pensée et le mouvant, Paris, Ellipses, 71-8.

SIPfLE David A., (1969), "On the Intelligibility of the Epochal Theory of Time," The Monist, 13, 505-18.

SIPfLE David A., (1969), "Henri Bergson and the Epochal Theory of Time," in P. A. Y. Gunter (ed.), Bergson and the Evolution of Physics, 1969, The University of Tennessee Press, Knoxville.

TEIXEIRA Maria Teresa, (2009), "Epochal Time and the Creativity of Thinking: Henri Bergson and Alfred North Whitehead," Concrescence - The Australasian Journal of Process Thought, 77-85, [ concrescence.org/index.php/ajpt/article/view/67/31].

TEIXEIRA Maria Teresa, (2010), “Whitehead, Processo e Realidade," in M. Weber \& R. Desmet (eds.), Chromatikon VI Annales de la philosophie en procès Yearbook of Philosophy in Process, Les éditions Chromatika.

VANZAGo Luca, (2005), L'Evento del Tempo. Saggio sulla filosofia del processo di A. N. Whitehead, Milano, Associazione Culturale Mimesis.

VERE C. Chapell, (1969), "Henri Bergson and the Epochal Theory of Time," in P.A.Y. Gunter (ed.), Bergson and the Evolution of Physics, Knoxville, The University of Tennessee Press.

WAHL Jean, (2004), Vers le concret. Études d'histoire de la philosophie contemporaine. William James, Whitehead, Gabriel Marcel, Paris, Librairie Philosophique J. Vrin.

WALLACK F. Bradford, (1980), The Epochal Nature of Process in Whitehead's Metaphysics, Albany, State University of New York Press.

WEBER Michel, (1999) “An Argumentation for Contiguism," in Streams of William James The Newsletter of William James Society, 1 (1), Spring, 11-3. [williamjamesstudies.org/streams.html]. WEBER Michel, (2000), "James's Contiguism of Pure Experience," in Streams of William James The Newsletter of William James Society, 1 (3), Winter, 19-22. [williamjamesstudies.org/streams.html]. 
WEBER Michel, (2003), “Whitehead's Reading of James and its Context (Part II)," in Streams of William James The Newsletter of William James Society, 5 (3), Fall, 26-33. [williamjamesstudies.org/ streams.html].

WEBER Michel, (2005), La dialectique de l'intuition chez Alfred North Whitehead, Frankfurt, Ontos Verlag.

WICKER Marie-Noëlle, (1998), "Passé, présent, futur. Vraies et fausses conceptions du temps," A nalyses et réflexions sur Henri Bergson La Pensée et le mouvant, Paris, ellipses, 67-70.

WHITEHEAD Alfred North, (1961), The Interpretation of Science, Selected Essays, A. H. Johnson (ed.), Indianapolis, New York, The Bobbs-Merrill Company, Inc.

WHITEHEAD Alfred North, (1967), Adventures of Ideas, New York, The Free Press.

WHITEHEAD, Alfred North, (1985), Process and Reality, Eds. David Ray Griffin and Donald W. Sherburne, New York, The Free Press.

WHITEHEAD Alfred North, (1997), Science and the Modern World, New York, The Free Press.

WHITEHEAD Alfred North, (2000), Concept of Nature, New York, Cambridge University Press.

\section{NOTES}

1. Principles of Psychology, vol. I, 239.

2. "Pragmatism and Humanism," in Writings 1902-10, 519.

3. “A Pluralistic Universe," Ibid., 751.

4. Principles of Psychology, vol. I, 225.

5. Principles of Psychology, vol. I, 237.

6. Principles of Psychology, vol. I, 233.

7. Principles of Psychology, vol. I, 240.

8. Principles of Psychology, vol. I, 243.

9. Principles of Psychology, vol. I, 243.

10. Mélanges, 579; Correspondances, 80.

11. Mélanges, 1418; Correspondances, 1052-55.

12. The Creative Mind, 178-9. The italics are mine.

13. Science and the Modern World, 125.

14. Science and the Modern World, 125.

15. Confessions, Book XI, XVIII, 23.

16. Confessions, Book XI, XX, 26.

17. Writings 1902-1910, 1061.

18. Writings 1902-10, 1061.

19. Physics 239b, 30.

20. "Some Problems of Philosophy," in Writings 1902-10, 1062.

21. p. 609-10.

22. "A Pluralistic Universe," Writings 1902-10, 760.

23. "Some Problems of Philosophy," Writings 1902-10, 1076-7.

24. Process and Reality, 35, [52].

25. Process and Reality, 35, [53].

26. Process and Reality, 67-9 [105]-[108]. Science and the Modern World, 124-7.

27. Process and Reality, 69 [107].

28. Science and the Modern World, 125. 
29. Science and the Modern World, 93.

30. Process and Reality, 68 [105].

31. L'évolution créatrice, 311.

32. Matter and Memory, 248; “Tout point de l'espace m'apparaissant nécessairement comme fixe, j'ai bien de la peine à ne pas attribuer au mobile lui-même l'immobilité du point avec lequel je le fais pour le moment coïncider; [...] Mais comment un progrès coïnciderait-il avec une chose, un mouvement avec une immobilité?," Matière et mémoire, 210.

33. "Au fond, l'illusion vient de ce que le mouvement, une fois effectué, a déposé le long de son trajet une trajectoire immobile sur laquelle on peut compter autant d'immobilités qu'on voudra. De là on conclut que le mouvement, s'effectuant, déposa à chaque instant au-dessous de lui une position avec laquelle il coïncidait. On ne voit pas que la trajectoire se crée tout d'un coup, encore qui lui faille pour cela un certain temps, et que si on peut diviser à volonté la trajectoire une fois créée, on ne saurait diviser sa création, qui est un acte en progrès et non pas une chose," L'évolution créatrice, 309.

34. The Creative Mind, 142. "Dirons-nous que la durée a de l'unité? Sans doute une continuité d'éléments qui se prolongent les uns dans les autres participent de l'unité autant que de la multiplicité, mais cette unité mouvante, changeante, colorée, vivante, ne ressemble guère à l'unité abstraite, immobile et vide, que circonscrit le concept d'unité pure," La pensée et le mouvant , 189.

35. Time and Free will, 128; Essai sur les données immédiates de la conscience, 95.

36. p. 275. "En réalité, il n'y a pas un rythme unique de la durée; on peut imaginer bien des rythmes différents, qui, plus lents ou plus rapides, mesureraient le degré de tension ou de relâchement des consciences, et, par là, fixeraient leurs places respectives dans la série des êtres," Matière et mémoire, 232.

37. Duration and Simultaneity, 52; “[...] toute durée est épaisse: le temps réel n'a pas d'instants," Durée et simultanéité, 51.

38. Principles of Psychology, 639.

39. Principles of Psychology, 609.

40. The Alternative, 167, quoted in Principles of Psychology, 609.

41. Principles of Psychology, 636.

42. Principles of Psychology, 636; cf. footnote.

43. Le bergsonisme, 55 .

44. The Creative Mind, 57-8, "Mais alors seulement nous nous aperçûmes que l'expérience interne à l'état pur, en nous donnant une 'substance' dont l'essence même est de durer et par conséquent de prolonger sans cesse dans le présent un passé indestructible, nous eût dispenser et même nous eût interdit de chercher où le souvenir est conservé. Il se conserve lui-même [...]," La pensée et le mouvant, 80.

45. Mind-Energy, 69.

46. Mind-Energy, 70. "Or, je crois bien que notre vis intérieur tout entière est quelque chose comme une phrase unique entamée dès le premier éveil de la conscience, phrase semée de virgules, mais nulle part coupée par des points. Et je crois par conséquent que notre passé tout entier est là subconscient - [...]," L'énergie spirituelle, 56-7.

47. Writings 1902-10, 457-60.

48. The Life Divine, 543-4.

49. The Journal of Philosophy, Psychology and Scientific Methods, 7 (4) (Feb. 17, 1910), 85-92.

50. The Journal of Philosophy, Psychology and Scientific Methods, 7 (4), 85-92.

51. "Response" Alfred North Whitehead The Interpretation of Science Selected Essays, 218.

52. Process and Reality, 215 [327]-[328]. 


\section{ABSTRACTS}

The Jamesian notion of the 'stream of consciousness' is closely related to the epochal theory of time. It also stems from an attempt to resolve the old aporia contained in Zeno's paradoxes. Time flows like a 'river' or a 'stream,' but still it grows by 'drops' or 'buds.' These basic units of time are whole and indivisible, but they do not 'crack' or 'divide' reality. Other process philosophies also include this notion of a continuous time that, nevertheless, integrates these interrelated units that account for individualisation without any breach of continuity. Henri Bergson's durée and Alfred N. Whitehead's epochal theory of time clearly illustrate this doctrine. The examination of memory and the status of the past as a positive existence also emphasise the temporal aspect of reality. Existing reality grows out of its past, which endures in the newborn actuality.

\section{AUTHOR}

\section{MARIA TERESA TEIXEIRA}

Universidad de Coimbra

mtmvteixeira[at]gmail.com 